Research Report

\title{
Toxicity Test on Taro Leaf Extract (Colocasia Esculenta L. Schoot) as Mouthwash to BHK-21 Fibroblast Cell Culture in Denture Users
}

\author{
Tiara Meilena, Januar Cidie Fabiansyah, Eha Djulaeha, Hanoem Eka Hidayati, \\ Department of Prosthodontics, Faculty of Dental Medicine \\ Universitas Airlangga \\ Surabaya - Indonesia
}

\begin{abstract}
Background: One of requirements for a material to be used in dentistry is that the material must be non toxic and non irritant, as well as have biocompatibility properties, not triggering a detrimental effect on the biological environment, both locally and systemically. The first-line tests that must be conducted is in vitro tests, one of which is MTT Assay. Samples used in this research were fibroblast cells (cultured BHK-21 cells) since fibroblasts are the most important and largest components in pulp, periodontal ligament, and gingiva. Purpose: This research aimed to determine toxicity effect of taro leaf extracts (Colocasia esculenta L. Schoot) on BHK-21 fibroblast cells. Methods: This research is an experimental laboratory research using Post Test Only Control Group design. The research treatment are the administration of Taro leaf extract (Colocasia esculenta L. Schoot) with 100\%, 80\%, 60\%, and $40 \%$ concentration on BHK-21 fibroblast cell. Results: The fibroblast cell life percentage in 100\%, 80\%, 60\%, and $40 \%$ concentration respectively are 106,3\%, 50,9\%, 36,2\%, and 30,1\%. The toxicity results are obtained using MTT assay technique after 24 hours. The optical density absorbency values are read by ELISA reader and represent life cell viability. Conclusion: Taro leaf extract (Colocasia esculenta L. Schoot) at a concentration above $80 \%$ is considered as non-toxic material to BHK-21 fibroblast cells.
\end{abstract}

Keywords: taro leaf extract, toxicity test, MTT Assay, BHK-21 fibroblast cells

Correspondence: Hanoem Eka Hidayati, Department of Prosthodontics, Faculty of Dental Medicine, Universitas Airlangga, Jl. Prof. Dr. Moestopo No. 47 Surabaya 60132 - Indonesia. Phone: +62315030255 E-mail: hanoem-eh@fkg.unair.ac.id

\section{INTRODUCTION}

The oral cavity is the part of the body where the food enters. The oral cavity has several parts such as teeth, gingival sulcus, tongue, cheeks, and palate. In the oral cavity found about 280 types of bacteria, most of which are normal flora and some abnormal flora. ${ }^{1}$

Denture base is part of the denture that is attached to the mucosa. The basic material of denture base can use acrylic or metal resin. Acrylic resin is the material most often used because it is cheaper and easier to apply. ${ }^{2}$ Microorganisms that are often found in dentures with acrylic material are Candida albicans. ${ }^{3}$ Candida albicans is one of the main organisms causing denture stomatitis because of its ability to attach and form biofilms in oral cavity tissue and denture surfaces and its resistance to antifungal agents. This biofilm can grow widely on removable denture acrylic resin material. ${ }^{4}$
Indonesia is a country that is rich in herbal plants that have been used for generations. One of the reasons and advantages of using herbal plants as medicine is cheap and easy to obtain..$^{5,6,7}$

Natural materials have been reported which can be used as mouthwashes and disinfectants. One of them is taro leaf. Taro leaf is one of the tubers with the scientific name Colocasia esculenta L. Schott. This plant rapid growth and easy to find in a humid environment. Taro has a high content of vitamin $\mathrm{C}$, oxalate, and phytochemicals such as phenols, tannins, steroids, quinine, terpenoids, glycosides, and alkaloids. All parts of taro are reported to have antimicrobial, antioxidant, and anticancer properties. This plant also contains saponin and flavonoid. Some of the active compounds above, as an antibacterial and antifungal, reduce the number of microorganism colonies in denture wearers. ${ }^{8}$ 
Materials that can be used in dentistry must be non-toxic, non-irritant, and must have biocompatibility properties. One method for testing the toxicity value of an ingredient is the MTT (Methyltiazolyldiphenyl - tetrazolium bromide) Assay method. This test is based on the ability of living cells to reduce salt 3- [4,5dimethylthiazol-2yl] -2,5-diphenyl tetrazolium bromide (MTT) which is yellow and dissolved to precipitate formazan which is purple and insoluble blue. ${ }^{9}$ Samples used in this research were fibroblast cells (BHK 21 cell culture). Fibroblast cells are the most important and largest component of the pulp, periodontal ligament and gingiva. Test results using BHK-21 can still be used as a basis for accurate testing. ${ }^{10}$

The purpose of study was to determine the toxicity of taro leaf extract (Colocasia esculenta (L.) Schott) extract on fibroblast.

\section{MATERIALS AND METHODS}

The ingredients used are taro leaf extract, BHK-21 fibroblast cells, distilled water, ethanol 96\%, media eagles, MTT (3- (4-5dymethylthiazol-2-yl) -2,5-diphenyl tetrazolium bromide), Versene trypsin, Fetal Bovine Serum $5 \%$, DMSO (dimethyl sulfoxide), PBS (Phosphate Buffered Saline). The research conducted was a laboratory experimental study with The Post Test Only Control Group Design research design. The treatment is by giving taro leaf extract to BHK 21 fibroblast cells. The preparation of extract material is carried out at the Research Institute and Industrial Consultation. Making tissue culture and research carried out at the Veterinaria Farma Center (PUSVETMA) Surabaya. Prepare fibroblast cells by thawing stem cell culture (seed cells) which had previously been frozen in sterile distilled water at $37^{\circ} \mathrm{C}$. After melting, the stem cell culture was centrifuged 1500 RPM for 15 minutes. The resulting supernatant is discharged in laminar flow so that the cell deposits remain at the bottom. The cell precipitate was taken and suspended with $36 \mathrm{ml}$ of Eagle's Minimum Essential Medium (EMEM) medium and $4 \mathrm{ml}$ of Fetal Bovine Serum (FBS) 5\%. Add $36 \mathrm{ml}$ of Eagles media to a bottle containing $4 \mathrm{ml}$ of serum so that the final result of $40 \mathrm{ml}$ of Eagles media and serum is obtained. The suspended cell deposit was planted in a sterile roux bottle, then incubated $37^{\circ} \mathrm{C}$, until the monolayer cells were formed $( \pm 2$ days, seen with a microscope). Fibroblast cells were taken from BHK-21 cell culture in the form of cell-lines implanted in Roux bottles. Media on Roux bottles containing BHK-21 fibroblast cells were discarded and washed with $15 \mathrm{~mL}$ Phosphate Buffer Saline (PBS) 3-5 times. Then the Roux Bottle is filled with $1 \mathrm{~mL}$ versene trypsine. The cells in the bottle will be seen clustered and then homogenized with $10 \mathrm{ml}$ of Eagle's Minimum Essential Medium (EMEM). Thus each well contains cells and Eagle media with a density of 2 x105 cells / ml. Cells were cultured in each well on a microplate of 96 well cells / $\mathrm{ml}$ for $50 \mu \mathrm{l}$ and incubated for 24 hours.

Observing the micro plate containing fibroblasts cells that have been incubated under a light microscope, whether fibroblasts cells that have been planted in each well have enough to do the treatment. Each treatment has 4 samples which are planted in 4 wells. The treatment was carried out by dropping every 4 samples with taro leaf extract with a concentration of $100 \%, 80 \%$, $60 \%$, and $40 \%$. Whereas, 4 samples for cell control and media control were not tested. Incubated for 24 hours in an incubator $37^{\circ} \mathrm{C}$, then transferred from the incubator.

MTT is dissolved in Phosphate-Buffered Saline (PBS) $5 \mathrm{mg} / \mathrm{ml}$. MTT was added $10 \mu \mathrm{l}$ to a plate containing culture medium, then reincubated for approximately 4 hours at $37^{\circ} \mathrm{C}$. All media in the wells and test material were taken. Then, each well was added $50 \mathrm{ml}$ DMSO (Dimethylsufoxide). The plate containing the culture medium was stirred mechanically with the Plate Shaker until the formazan crystals dissolved, for 5 minutes. The living fibroblasts cells will be colored with formazan becoming purplish blue, while the dead cell do not form a purplish blue color. Furthermore, the formazan absorbance was read spectrophotometrically with an ELISA reader at a wavelength of $620 \mathrm{~nm}$. The more concentrated the color, the higher the absorption value and the more number of living cells.

The percentage of cell life is calculated using the following formula : ${ }^{13}$

$\%$ Cell Life $=$ Test Group + Media $\times 100 \%$ Cell + Media 
Information:

$\%$ of cell life : percentage of cell life count after test

Test group : value of OD (optical density) formazan each sample after the test

Media : the value of OD (optical density) formazan on the average of each control media

Cells : the value of the OD (optical density) formazan on the average control cell

\section{RESULTS}

Table 1 shows the optical average of density with various concentrations and calculated using the $\%$ cell life formula to obtain the percentage of fibroblast cell life from 4 samples per test group after treatment of taro leaf extract.

Table 1. Optical average rates of density of taro leaf extract and live cell percentage

\begin{tabular}{|c|c|c|}
\hline Treatment & OD Mean & $\begin{array}{c}\text { Percentage of } \\
\text { living cells }\end{array}$ \\
\hline Control Media & 0.061 & - \\
Control Cells & 0.367 & - \\
$100 \%$ & 0,394 & $106,3 \%$ \\
$80 \%$ & 0.157 & $50,9 \%$ \\
$60 \%$ & 0.094 & $36,2 \%$ \\
$40 \%$ & 0.081 & $33,1 \%$ \\
\hline
\end{tabular}

Based on the calculation of cell life\% obtained results of taro leaf extract with $100 \%$ concentration yields highest cell viability, while taro leaf extract with concentration of $40 \%$ yields the lowest cell viability.

\section{DISCUSSION}

Taro leaves are tropical plants of the Araceae tribe. Leaf stem taro cylindrical shape with a length of $50-75 \mathrm{~cm}$, single and wide. Leaflets shaped like an elongated heart, flat edges, pointed edges, curved base, and dark green. ${ }^{11}$

Taro leaf has many benefits and potential as one of the ingredients in the medical field. However, the use of drugs whether used systemically or locally may not be toxic and should not have a detrimental effect on the human body. ${ }^{12}$ In this study conducted a toxic test to develop the use of taro leaf extract in the oral cavity as a disinfectant or mouthwash with concentration $100 \%, 80 \%, 60 \%$, and $40 \%$ based on trial trials that have been done.

The toxicity test using the MTT Assay method was carried out using BHK-21 fibroblast cell culture. This cell was chosen because it is derived from embryonic cells that can be easily grown, easily cultured, has a character that is quite stable, sensitive and not mutated. Primary BHK-21 cells were obtained from Veterinaria Farma Center (PUSVETMA) Surabaya and then cultured into cell lines and used in toxicity tests. At the time of the splinting cell line process, we need a media that can support cell growth. In this research, Eagle media containing vitamins, amino acids, salt, and glucose were used. ${ }^{13}$

Based on table 1 can be seen the percentage of life of fibroblast cells that get treated taro leaf extract with a concentration of $100 \%, 80 \%, 60 \%$, and $40 \%$ of BHK-21 fibroblast cells using the MTT Assay method sequentially has a percentage of living cells of $106,3 \%, 50.9 \%, 36.2 \%$ and $33.1 \%$. From these results it can be seen that the percentage of fibroblast cells of more than $50 \%$ is found at concentrations of $100 \%$ and $80 \%$. These results indicate that the taro leaf extract at a concentration of $100 \%$ and $80 \%$ is not toxic. An ingredient is said to be toxic if the percentage of living cells after exposure to the material is less than $50 \% .^{10,12}$

The MTT Assay test results in this study which formed purplish blue reactions only occur at concentrations of $100 \%$ and $80 \%$. In the MTT Assay test a color change occurs because there is a change in tetrazolium salt into formazan in the mitochondria that are active in living cells. The mechanism, yellow formazan tetrazolium salt will be reduced in cells that have metabolic activity. Mitochondria are cells that play an important role in producing inactive dehydrogenase due to cytotoxic effects, so formazan does not form a purplish blue reaction used as a measure of the number of living cells. The darker the blue color, the higher the absorbance value and the more number of living cells. ${ }^{14}$ However, if the cell color fades, the absorbance value decreases, meaning that more cells die. ${ }^{15,16}$ The mechanism and intensity of cell 
death depend on the level of material or drug in contact with cells. A stimulus can damage cells that are reversible and irreversible. The ability of cells to survive can be interpreted as no metabolic loss or proliferation and can be measured by increasing the number of cells, increasing the amount of protein, or the amount of DNA synthesized. ${ }^{17,18}$

From visual observations it appears that the cell culture given taro leaf extract has a lighter color than the control cell group. This shows that in the culture of fibroblast cells given taro leaf extract the number of living cells is less than the number of living fibroblasts in the control cell.

Microscopic evaluation of the MTT Assay test revealed differences in the morphology of fibroblast cells in the control cell group and the treatment group. In the control cell group fibroblasts are in good condition with intact cell nuclei. Whereas the treatment group found dead fibroblast cells, visible cell membrane damage, invisible cell nucleus or lysis.

In this study, simplicia, processing and identification of taro leaves were obtained and carried out by the Surabaya Laboratory Industry Consultation Research Agency. Toxic leaf extract toxicity testing was carried out at the PUSVETMA Laboratory. Based on phytochemical tests conducted at the Surabaya Laboratory of Industrial Consultation Research Center, taro leaf extract contains $3.20 \%$ flavonoids, tannins $1.05 \%$, and $3.56 \%$ saponins. The content of these compounds has antibacterial, antifungal, anti-inflammatory, and antimicrobial effects. Saponins and tannins stimulate growth factor secretion which can affect fibroblast proliferation. However, besides having properties that increase proliferation, there are active compounds that trigger a decrease in cell counts. ${ }^{19}$

Saponin is one of the ingredients found in taro leaf extract which has hemolytic activity, lysis leukocyte cells, increases the permeability of cell membranes that will make lysis and cellular leakage occur. The formation of cholesterol complexes affects pores in cell membranes and cell transportation through aquaporins. Increased transportation through aquaporins causes cells to become swollen and burst and then die or is called an osmotic shock effect. ${ }^{21}$
In this study, when serial dilution of the extract was carried out, it was possible to not find the same active ingredient component in each concentration. Though the content in these cells can affect the proliferation of BHK-21 fibroblast cells, so that the average value of the cell life does not show consistent results (Jayanti, 2013). In addition there are other factors such as the type of culture media and the filter set (filter set).$^{21}$

The results of laboratory experimental research on the toxicity of taro leaf extract against BHK-21 cells using MTT Assay can be concluded that taro leaf extract with the highest concentration is said to be non-toxic to BHK-21 cells because at higher concentrations it can increase the proliferation of fibroblast cells. In addition, in this study which has a concentration of $60 \%$ and $40 \%$ can not be said with certainty the toxicity of taro leaf extract even though this study shows the presence of toxic properties at both concentrations. The active compound saponin content in taro leaf extract has toxic properties and it cannot be ascertained the extract content in each serial dilution.

The results of toxicity test of taro leaf extract on BHK-21 fibroblas cells showed that taro leaf extract with concentration above $80 \%$ did not show toxic effect on BHK-21 fibroblas cells.

\section{REFERENCES}

1. Dewhirst, F., Chen, T., Izard, J., Paster, B., Tanner, A., Yu, W., Laksmanan, A. and Wade, W. 2010. The Human Oral Microbiome. Journal of Bacteriology, 192(19), Pp.5002-5017.

2. Nallaswamy, D., 2003, Textbook of Prosthodontics, Jaypee Brothers Medical Publishers, New Delhi. Pp. 4-5.

3. Annusavice Kenneth J., Ralph Chiayi Shen, H. 2013. Phillips' Science of Dental Materials $12^{\text {th }}$ Ed. Missouri: Elsevier. P. 494.

4. Faot, F, Cavalcanti, Y, de Mendonça e Bertolini, M, de Rezende Pinto, L, da Silva, W, \& Del Bel Cury, A 2014, 'Efficacy of citric acid denture cleanser on the Candida albicans biofilm formed on poly(methyl methacrylate): effects on residual biofilm and recolonization process', BMC Oral Health 14 (1): Pp. 1-15.

5. Supreetha S, Mannur S, Simon SP, Jain J, Tikare S, Mahuli A. Antifungal Activity of Ginger Extract on Candida Albicans: An Invitro Study. J Dent Sci and Res. 2011; 2(2): Pp. 18-21. 
6. Zein. 2005. Pemanfaatan Tumbuhan Obat Dalam Upaya Pemeliharaan Kesehatan. e-USU Repository Universitas Sumatera Utara.

7. Jayanti, Titik. 2013. Uji Toksisitas Ekstrak Buah Delima Merah (Punica granatum) pada Kultur Sel Fibroblast BHK-21. Skripsi. Fakultas Kedokteran Gigi Universitas Airlangga. Pp. 1-6

8. Biren, N.S., Nayak, B.S, Bhatt,S.P, Jalalpure.,S.S., Seth., A.K. 2007. The AntiInflamatory Activity of The Leaves of Colocasia esculenta. SPJ. 15. Pp. 3-4.

9. Hughes, D and Mehmet, H. 2003. Cell Proliferation and Apoptosis. Oxford: BIOS Scientific Pub. Ltd. Pp. 18-23.

10. Meizarini, Asti. 2005. Sitotoksisitas bahan Restorasi Cyanoacrylate pada Variasi Perbandingan Powder dan Liquid menggunakan MTT Assay. Majalah Kedokteran Gigi (Dental Journal). 38, Pp. 20-24.

11. Dalimartha, S. 2006. Atlas Tumbuhan Obat Indonesia Jilid 4. Jakarta : Puspa Swara. Pp. 9395.

12. Freshney, RI. 2010. Culture of Animal Cell: a manual of basic technique 4th Ed. New York. Willey Liss Inc. Pp. 89.

13. Khoswanto,C. 2008. Uji Sitotoksisitas Dentin Kondisioner Asam Sitrat 50\% menggunakan MTT Assay. Dental Journal. 41, Pp. 103-106.

14. Neviyanti, 2004. Biokompabilitas irigasi saluran akar. Medan: e Jornal USU. Hal.1.
15. Fazwishni S dan Hadijono B.S., 2000. Uji Sitotoksisitas dengan Esei MTT. Jurnal Kedokteran Gigi Universitas Indonesia; 7 (Edisi Khusus). Pp. 28-32.

16. Hadijono, BS. Fazwishni, S. 2000. Uji Sitotoksisitas dengan esei MTT. Jurnal Kedokteran gigi Universitas Indonesia. Ed 7. Pp. 28-32.

17. Dirix, Pitt, et al. 2006. Efiicacy of the BioXira dry mouth care system in the treatment of adiotherapy-induced xerostomia. Support Care Cancer. 15, Pp. 1429-1436.

18. Soenartyo H dan Rianti D. 2003. Uji Sitotoksitas Ekstrak Colus Amboinicuc Lour menggunakan Esei MTT: Majalah Kedokteran Gigi (Dental Journal). Pp. 36(2).

19. Sakagami Hiroshi, Tatsuya Kushida, Toru Makino., etall. 2012. Functional Analysis of Natural Polyphenols and Saponins as Alternative Medicines. Pp. 278-283.

20. Casasus I, Rogosic J, Rosati A, Stokovic I, and Gabina D 2012. Animal Farming and Environmental Interactions in the Mediterranean Region. Wageningen Academic Publisher. Wageningen. P. 46.

21. Hansson, J. 2012. Microfluidic Blood Sample Preparation for Rapid Sepsis Diagnostic. Thesis. Stockholm. Pp. 13-4. 